\title{
KEDUDUKAN HUKUM PIDANA TERKAIT ADANYA PEREDARAN NARKOTIKA DI INDONESIA DITINJAU DARI UNDANG-UNDANG NOMOR 35 TAHUN 2009 TENTANG NARKOTIKA
}

\author{
Oleh : \\ Rahmad Teguh \\ Email:rahmadteguh05@yahoo.com \\ Universitas Narotama Surabaya
}

\begin{abstract}
Abstrak
Penulisan ini mengkaji atau menganalisis data sekunder yang berupa bahan-bahan hukum sekunder dengan memahami hukum sebagai perangkat peraturan atau norma-norma positif di dalam sistem perundang-undangan yang mengatur mengenai kehidupan manusia (library research). Berdasarkan hasil penelitian tersebut diketahui bahwa penegakan hukum terhadap kejahatan Narkotika menurut Undang- Undang Narkotika dikenakan sanksi pidana penjara, pidana denda, pidana seumur hidup dan sanksi lainnya, Perlindungan bagi anak penyalahgunaan Narkotika ditinjau dari Aspek Viktimologi yaitu direhabilitasi karena anak tersebut disatu sisi menjadi pelaku dan sisi lainnya menjadi korban, Peredaran Narkotika ditinjau dari hukum internasional yaitu kebijakan penanggulangan kejahatan narkotika pada awalnya dituangkan dalam The United Nation\&\#39;s Single Convention on Narcotic Drugs 1961.
\end{abstract}

Kata Kunci: Kejahatan Narkotika, Era Perdagangan Bebas Internasional, Keamanan dan Kedaulatan Negara.

\begin{abstract}
This study is understood as a library research (library research), such as a study on secondary data. In conclusion, the law enforcement against Narcotic Crimes according to Law on Narcotics shall give sanction of imprisonment, criminal fines, life imprisonment and other sanctions. The protection of child abuse of narcotics from victimology aspects is rehabilitated due to the child as a perpetrator and victim. The International Law on drug trafficking is the policy on preventing narcotic crimes originally provided in the United Nation\&\#39;s Single Convention on narcotic drugs in 1961.
\end{abstract}

Keywords: Narcotic Crimes, the Era of International Free Trade, Security and State Sovereignty. 


\section{PENDAHULUAN}

\subsection{Latar Belakang Masalah}

Narkotika adalah zat atau obat yang berasal dari tanaman atau bukan tanaman, baik sintesis maupun semisintesis yang dapat menyebabkan penurunan atau perubahan kesadaran, hilangnya rasa, mengurangi dan menghilangkan rasa nyeri, serta menimbulkan ketergantungan. Begitu pula dengan psikotropika, adalah zat atau obat, baik alamiah maupun sintesis bukan narkotika, yang berkhasiat psikoaktif melalui pengaruh selektif pada susunan saraf pusat yang menyebabkan perubahan khas pada aktivitas mentaldan perilaku. Narkotika adalah zat atau obat yang berasal dari tanaman atau bukan tanaman, baik sintesis maupun semisintesis, yang dapat me-nyebabkan penurunan atau perubahan kesadaran, hilangnya rasa, mengurangi sampai menghilangkan rasa nyeri, dan dapat menimbulkan ketergantungan, yang dibedakan ke dalam golongan-golongan sebagaimana terlampir dalam undang-undang ini. ${ }^{3}$

Penggunaan narkotika sering dikaitkan dengan kejahatan,baik narkoba dianggap memiliki pengaruh negatif dan menyebabkan penggunanya melakukan kejahatan. Kejahatan itu pada dasarnya merupakan rumusan yang nisbi. Mustafa mengatakan bahwa yang disebut kejahatan sebagai gejala sosial tidak semata-mata merupakan tindakan yang dilarang hukum, tindakan yang merupakan kelaianan biologis maupun kelaianan psikologis, tetapi tindakan-tindakan tersebut merugikan dan melanggar sentimen masyarakat. ${ }^{1}$ Jika kita mengacu pada rumusan kejahatan sebagaimana yang dijelaskan oleh Mustafa, titik tekan penentuan apakah suatu perilaku dianggap kejahatan atau tidak bukanlah menjadikan aturan formal sebagaiacuan. ${ }^{2}$

Sebagai kejahatan narkotika yang sudah sejak lama menjadi musuh bang-sa, kini narkotika sudah sangat mengkhawatirkan bangsa kita dan seluruh bangsa di dunia saat ini. Produksi dan peredaran narkotika begitu masif beredar di tengah-tengah masyarakat kita.Peran dari para mafia narkotika seakan seperti tdak dapat terbendung lagi. Para mafia narkotika sudah meracuni para penegak hukum sebagai pengguna maupun sebagai pengedar di bangsa Indonesia dan berbagai belahan dunia, walaupun seluruh bangsa memerangi kejahatan ini. Masyarakat sering mendengar pernyataan tentang membangun komitmen atau memerangi bersama dalam memberantas narkotika di negara Indonesia dan seluruh

\footnotetext{
${ }^{1}$ Mustafa, Muhammad, Krimonologi, 2007: Kajian Sosiologi terhadap Kriminalitas, Perilaku menyimpang, dan Pelanggar Hukum, FISIP UI Press, hlm.17.

${ }^{2}$ Bhakti Eko Nugroho, htpp://catatan-orangbiasa.blogspot.com/2008/12/benarkah penggunaan-drugs-adalah.html.
} 
dunia.

Penyalahgunaan Narkotika telah meluas disebagian kalangan masyarakat di kota-kota besar maupun kota-kota kecil bahkan peredaran sulit dihentikan. Penyalahgunaan narkotika digunakan tidak untuk tujuan mengobati penyakit, akan tetapi digunakan dengan sengaja untuk mencapai "kesadaran tertentu" karena pengaruh obat pada jiwa. Sebagai masyarakat Indonesia yang pada umumnya saat ini sedang dihadapkan pada keadaan yang sangat susah mengkhawatirkan akibat maraknya pemakaian, secara sembarangan macam-macam narkotika maupun psikotropika. $^{3}$

Pada dasarnya peredaran narkotika di Indonesia sudah sangat luas.Undangundang No. 35 Tahun 2009 Tentang Narkotika telah memberi perlakuan yang berbeda bagi pelaku penyalahgunaan narkotika. Pengguna atau pecandu narkotika sebagai pelaku tindak pidana narkotika adalah dengan pidana penjara yang diberikan pada para pelaku penyalahgunaan narkotika.

\subsection{Perumusan Masalah}

Berdasarkan latarbelakang yang telah dipaparkan di atas, maka permasalahan yang akan diteliti dapat dirumuskan sebagai

\footnotetext{
${ }^{3}$ Kaka Alvian Nasution, 2014, Himpunan Lengkap Undang-Undang Narkotika dan Psikotropika, Saufa, Jogyakarta, hlm154
}

berikut :

1. Bagaimana sistem hukum pidana di Indonesiaterkait adanya tindak pidana narkotika?

2. Apa bentuk perlindungan hukum bagi pelaku dan korban sebagai penyalaguna peredaran narkotika?

\section{METODE PENELITIAN}

Tulisan ini menggunakan metode penelitian hukum normatif, yaitu meneliti hukum dari perspektif internal dengan objek penelitiannya adalah norma hukum. Dengan kata lain penelitian hukum yang meletakkan hukum sebagai sebuah bangunan sistem norma. Sistem norma yang dimaksud adalah mengenai asas- asas, norma, kaidah dari peraturan perundangan, putusan pengadilan, perjanjian serta doktrin (ajaran). ${ }^{4}$

Pendekatan yang digunakan adalah pendekatan perundang-undangan dan pendekatan konseptual. Pendekatan perundangundangan atau statute approach digunakan jika permasalahan penelitiannya mempermasalahkan konflik norma yang terjadi secara vertikal maupun horizontal. Dalam setiap penelitian atau survei terhadap sesuatu masalah dapatlah digunakan bermacam-macam cara atau metode seperti

${ }^{4}$ I Made Pasek Diantha, 2016, Metodologi Penelitian Hukum Normatif dalam Justifikasi Teori Hukum (Jakarta : Prenada Media Grup) .hlm.12 
melakukan penelitian atau survei secara kepustakaan, melakukan interview dan sebagainya.

Pendekatan konseptual atau conceptual approach beranjak dari pandanganpandangan dan doktrin-doktrin yang berkembang di dalam ilmu hukum, sehingga dapat menemukan ide-ide yang melahirkan pengertian-pengertian hukum, konsepkonsep hukum, dan asas-asas hukum yang relevan dengan isu yang dihadapi. ${ }^{5}$

\section{HASIL DAN PEMBAHASAN}

\subsection{Sistem Hukum Pidana Indonesia Di Indonesia Terkait Adanya Tindak Pidana Narkotika}

Narkotika adalah zat atau obat yang berasal dari tanaman atau bukan tanaman, baiksintetis maupun semisintetis, yang dapat menyebabkan penurunan atau perubahan kesadaran, hilangnya rasa, mengurangi sampai menghilangkan rasa nyeri, dan dapat menimbulkan ketergantungan. Dapat dikatakan bahwa, di satu sisi narkotika merupakan obat atau bahan yang bermanfaat di bidang pengobatan, pelayanan kesehatan, dan pengembangan ilmu pengetahuan, namun disisi lain dapat menimbulkan ketergantungan yang sangat merugikan apabila dipergunakan tanpa adanya pengendalian serta pengawasan yang ketat dan

${ }^{5}$ Ibid, hlm. 159

JURNAL RECHTENS, Vol. 9, No. 1, Juni 2020 seksama. Dalam hal ini, apabila ditinjau dari aspek yuridis maka keberadaan narkotika adalah sah. UU Narkotika hanya melarang penggunaan narkotika tidak sesuai dengan ketentuan undang-undang.

Keadaan yang demikian ini dalam tataran empirisnya mengakibatkan narkotika sering disalahgunakan bukan untuk kepentingan pengobatan dan ilmu pengetahuan, melainkan dijadikan ajang bisnis yang menjanjikan dan berkembang pesat, yang mana kegiatan ini berimbas pada rusaknya fisik maupun psikis mental semua lapisan masyarakat. Dari segi usia, narkotika tidak hanya dinikmati golongan remaja saja, tetapi juga golongan setengah baya maupun golongan usia tua. Penyebaran narkotika tidak lagi terbatas dikota besar, tetapi sudah masuk kota- kota kecil dan merambah ke kecamatan bahkan desadesa. $^{6}$

Menurut psikiater Graham Blaine, sebab-sebab penyalahgunaan narkotika adalah sebagai berikut: ${ }^{7}$

a. untuk membuktikan keberanian dalam melakukan tindakan-tindakan yang berbahaya dan mempunyai resiko

b. untuk menantang suatu otoritas terhadap orangtua, guru, hukum atau instansi berwenang;

\footnotetext{
${ }^{6}$ Hari Sasangka,2011, Narkotika dan Psikotropika Dalam Hukum Pidana, Bandung: Mandar Maju, hlm. 55

${ }^{7}$ Ibid,
} 
c. untuk mempermudah penyaluran dan perbuatan seksual ;

d. untuk melepaskan diri dari rasa kesepian dan ingin memperoleh pengalaman-pengalaman emosional untuk berusaha agar dapat menemukan arti hidup;

e. untuk mengisi kekosongan dan mengisi perasaan bosan, karena kurang kesibukan;

f. untuk menghilangkan rasa frustasi dan kegelisahan yang disebabkan oleh problema yang tidak bisa diatasi dan jalan pikiran yang buntu, terutama bagi mereka yang mempunyai kepribadian yang tidak harmonis;

g. untuk mengikuti kemauan kawan dan untuk memupuk solidaritas dengan kawan-kawan; dankarena didorong rasa ingin tahu (curiosity) dan karena iseng (just for kicks)

Penyebab penggunaan narkotika secara tidak legal yang dilakukan oleh para remaja dapatlah dikelompokkan tiga keinginan yaitu: ${ }^{8}$

a. mereka yang ingin mengalami (the experience seekers) yaitu ingin memperoleh pengalaman baru dan sensasi dari akibat pemakaian narkotika;

b. mereka yang bermaksud menjauhi atau mengelakkan realita hidup (the oblivion

\footnotetext{
${ }^{8}$ Soedjono Dirdjosisworo,2013, Pathologi Sosial, Bandung: Alumni, hlm. 70-71.
}

seekers) yaitu mereka yang menganggap keadaan terbius sebagai tempat pelarian terindah dan ternyaman; dan

c. mereka yang ingin merubah kepribadiannya (personality change) yaitu mereka yang beranggapan menggunakan narkotika dapat merubah kepribadian, seperti menjadi tidak kaku dalam pergaulan. Sedangkan untuk orangorang dewasa dan yang telah lanjut usia, alasan menggunakan narkotika yaitu sebagai berikut :

a. menghilangkan rasa sakit dari penyakit kronis;

b. menjadi kebiasaan (akibat penyembuhan dan menghilangkan rasa sakit);

c. pelarian dari frustasi; atau

d. meningkatkan kesanggupan untuk berprestasi (biasanya sebagai zat perangsang).

Pemberantasan narkotika tentunya tidak dapat ditekan jika aparat penegak hukum hanya fokus pada level para pengguna. Seharusnya penguna maupun pecandu ditempatkan sebagai korban ataupun pasien yang harus direhabilitasi, dan yang menjadi target operasi kepolisian adalah para pengedar/bandar. Logikanya, dengan menangkap pengguna maka tentunya dapat membantu untuk menangkap pengedarnya yang kemudian pengguna dengan kategori tertentu dapat dijatuhi 
vonis rehabilitasi seperti yang diamanahkan dalam Surat Edaran Mahkamah Agung (SEMA) Nomor 7 Tahun 2009 tentang Menempatkan Pemakai Narkoba ke dalam Panti Terapi dan Rehabilitasi.

Sedangkan untuk pengedarnya diberikan sanksi pidana secara tegas bahkan jika mencukupi syarat dapat langsung divonis hukuman mati. Dapat dikatakan bahwa disatu sisi ada semangat yang luar biasa dalam pemberantasan narkotika dan precursornarkotikadalamUUNarkotika,nam un di sisi lain juga tercermin semangat melindungi penyalahgunaan narkotika baik sebagai pecandu maupun sebagai korban penyalahgunaan narkotika.

Ruang lingkup hukum pidana mencakup tiga ketentuan yaitu tindak pidana, pertanggungjawaban, dan pemidanaan. Ketentuan pidana yang terdapat dalam UU No. 35 Tahun 2009 tentang Narkotika dirumuskan dalam Bab XV Ketentuan Pidana Pasal 111 sampai dengan Pasal 148. UndangUndang No. 35 Tahun 2009 tentang Narkotika, terdapat empat kategorisasi tindakan melawan hukum yang dilarang oleh undang- undang dan dapat diancam dengan sanksi pidana, yakni: ${ }^{9}$

1. Kategori pertama, yakni perbuatanperbuatan berupa memiliki, menyimpan, menguasai atau menyediakan narkotika

\footnotetext{
9 Siswanto Sunarso,2012, Politik Hukum Dalam Undang-Undang Narkotika, Jakarta:Rineka Cipta, hlm. 256
}

JURNAL RECHTENS, Vol. 9, No. 1, Juni 2020 dan prekursor narkotika (Pasal 111 dan 112 untuk narkotika golongan I, Pasal 117 untuk narkotika golongan II dan Pasal 122 untuk narkotika golongan III serta Pasal 129 huruf (a));

2. Kategori kedua, yakni perbuatanperbuatan berupa memproduksi, mengimpor, mengekspor, atau menyalurkan narkotika dan precursor narkotika (Pasal 113 untuk narkotika golongan I, Pasal 118 untuk narkotika golongan II, dan Pasal 123 untuk narkotika golongan III serta Pasal 129 huruf(b));

3. Kategori ketiga, yakni perbuatanperbuatan berupa menawarkan untuk dijual, menjual, membeli, menerima, menjadi perantara dalam jual beli, menukar, atau menyerahkan narkotika dan prekursor narkotika (Pasal 114 dan Pasal 116 untuk narkotika golongan I, Pasal 119 dan Pasal 121 untuk narkotika golongan II, Pasal 124 dan Pasal 126 untuk narkotika golongan III serta Pasal $129 \operatorname{huruf}(\mathrm{c}))$;

4. Kategori keempat, yakni perbuatan-perbuatan berupa membawa, mengirim, mengangkut atau mentransit narkotika dan prekursor narkotika (Pasal 115 untuk narkotika golongan I, Pasal 120 untuk narkotika golongan II dan Pasal 125 untuk narkotika golongan III serta Pasal $129 \operatorname{huruf}(d))$. 
Pasal 136 UU No. 35 Tahun 2009 memberikan sanksi berupa narkotika dan prekursor narkotika serta hasil-hasil yang diperoleh dari tindak pidana narkotika baik itu aset bergerak atau tidak bergerak maupun berwujud atau tidak berwujud serta barang-barang atau peralatan yang digunakan untuk tindak pidana narkotika dirampas untuk negara.

Pasal146 UU No. 35 Tahun 2009 juga memberikan sanksi terhadap warga negara asing yang telah melakukan tindak pidana narkotika ataupun menjalani pidana narkotika yakni dilakukan pengusiran wilayah negara Republik Indonesia dan dilarang masuk kembali ke wilayah negara Republik Indonesia. Sedangkan pada Pasal 148 bila putusan denda yang diatur dalam undangundang ini tidak dibayarkan oleh pelaku tindak pidana narkotika maka pelaku dijatuhi penjara paling lama dua tahun sebagai pengganti pidana denda yang tidak dapat dibayar.

BNN, Kepolisian, Kejaksaan, Hakim dan penegak hukum lainnya termasuk juga komponen masyarakat mempunyai tanggung jawab untuk melakukan penanggulangan dan pencegahan terhadap penyalahgunaan narkotika. Hal tersebut merupakan amanat dari peraturan perundang-undangan, termasuk dalam hal ini UUN arkotika.

Pencegahan penyalahgunaan narkotika harus sesegera mungkin dilakukan dengan tindakan yang bersifat antisipatif, meliputi pencegahan primer, pencegahan skunder, dan pencegahan tersier, seperti berikut ini: ${ }^{10}$

\section{PencegahanPrimer}

adalah pencegahan yang ditujukan kepada individu, kelompok atau masyarakat luas yang belum terkena kasus penyalahgunaan narkoba. Pencegahan diberikan dengan memberikan informasi dan pendidikan meliputi kegiatan alternatif agar mereka terhindar dari penyalahgunaan narkoba serta memperkuat kemampuannya untuk menolak.

2. Pencegahan Sekunder adalah pencegahan yang ditujukan kepada individu, kelompok atau masyarakat luas yang rentan terhadap atau lebih menunjukkan adanya kasus penyalahgunaan narkoba. Pencegahan ini dilakukan melalui jalur pendidikan, konseling, dan pelatihan agar mereka berhenti, kemudian melakukan kegiatan positif dan menjaga agar mereka tetap lebih mengutamakankesehatan.

\section{PencegahanTersier}

adalah pencegahan yang ditujukan kepada mereka yang sudah menjadi pengguna atau yang telah menderita ketergantungan. Pencegahan dapat dilakukan melalui pelayanan medis, rehabilitasi, dan menjaga agar mereka tidak kambuh dansakaw.

\footnotetext{
${ }^{10}$ Yusuf Apandi,2012, Katakan Tidak Pada Narkoba , Bandung: Simbiosa Rekatama Mebia, hlm.22.
} 


\subsection{Bentuk Perlindungan Hukum Bagi} Pelaku Dan Korban Sebagai Penyalahguna Peredaran Narkotika

Pengertian Penyalahgunaan Narkotika Menurut Pasal 1 angka 15 Undang-Undang No. 35 Tahun 2009 penyalahguna narkotika adalah orang yang menggunakan narkotika tanpa hak atau melawan hukum. Untuk menentukan suatu perbuatan itu bersifat tanpa hak atau melawan hukum perlu diketahui terlebih dahulu dasar aturan hukum yang menentukan orang untuk bisa mempergunakan narkotika. Didalam regulasinya Undang-Undang No. 35 Tahun 2009 memandang bahwa pengguna narkotika dan korban penyalahgunaan narkotika merupakan dua hal yang berbeda, penyalahgunaan narkotika adalah penggunaan tanpa hak dan melawan hukum yang dilakukan tidak untuk maksud pengobatan, tetapi karena ingin menikmati pengaruhnya, dalam jumlah berlebih, kurang teratur, dan berlangsung cukup lama, sehingga menyebabkan gangguan kesehatan fisik, mental dan kehidupan sosial.

Menurut penjelasan Pasal 54 UndangUndang No. 35 Tahun 2009, korban penyalahgunaan narkotika adalah seseorang yang tidak sengaja menggunakan narkotika karena dibujuk, diperdaya, ditipu, dipaksa, dan/atau diancam untuk menggunakan narkotika. Dengan demikian seorang korban penyalahgunaan narkotika harus terbukti tidak mempunyai unsur kesengajaan mempergunakan narkotika secara melawan hukum dikarenakan adanya keadaan (seperti dipaksa atau diancam) yang membuat ia mau tidak mau menggunakan narkotika atau karena ketidaktahuan yang bersangkutan kalau yang digunakannya adalah narkotika (seperti ditipu, dibujuk, atau diperdaya).

Sementara untuk memaparkan bagaimana kedudukan korban narkotika dalam ilmu hukum beserta hak-haknya, serta pentingnya eksistensi rehabilitasi bagi penyalah guna narkotika, maka korban penyalah guna narkotika tidak dipidana, karena pengguna narkotika terutama yang sudah ada dalam tahap kecanduan didudukkan sebagai korban yang sepatutnya direhabilitasi baik secara medis ataupun sosial.

Pelaku dan korban penyalahgunaan narkotika haruslah mendapat perlindungan hukum. Tindak pidana narkotika oleh penyalahguna merupakan permasalahan yang berhubungan dengan misi perbaikan perlakuan manusia, serta sangat besar serta sangat besar pengaruhnya dalam mencegah dan mengurangi kejahatan terutama pada tindak pidana narkotika. Masalah ini tidak saja bermaksud melindungi kepentingan perseorangan tetapi juga melindungi kepentingan kepentingan masyarakat dan negara.

Upaya untuk perlindungan yang diberikan terhadap pelaku dan korban penyalagunaan narkotika adalah berupa : 
a. Melindungi hak-hak pelaku dan korban penyalahgunaan narkotika selama menjalani persidangan.

b. Memberikan bantuan hukum secara cuma-cuma dengan memberikan kuasa hukum untuk mendampingi pelaku dan korban untuk menjalani persidangan.

c. Memberikan putusan peradilan yang merujuk pada pelaku dan korban penyalahgunaan narkotika untuk menjalani rahabilitasi yang bekerja sama dengan panti rehabilitasi, departemen kesehatan dan departemen sosial dengan dasar hukum Pasal 54 UU Nomor 35 Tahun 2009 tentang Narkotika ( pecandu narkotika dan korban penyalahgunaan narkotika wajib menjalani rehabilitasi medis dan rehabilitasi sosial).

Pelaksanaan rehabilitasi bagi pecandu narkoba sebagai pengganti dari sanksi hukuman yang bersifat kurungan pinjara diadopsi dari model doble track system, yaitu yang merupakan sistem dua jalur mengenai sanksi dalam hukuman pidana, yakni jenis sanksi pidana dan jenis sanksi tindakan. Artinya, fokus sanksi pidana ditujukan pada perbuatan salah yang telah dilakukan seseorang melalui pengenaan penderitaan agar yang bersangkutan menjadi jera. Sementara fokus sanksi tindakan lebih terarah kepada upaya pemberian pertolongan pada pelaku agar dia berubah. Dalam arti lain, bahwa sanksi pidana bertujuan pada pembalasan terhadap si pelaku, sedangkan sanksi tindakan bertujuan untuk memberi perlindungan, perawatan dan pembinaan kepada masyarakat, khususnya bagi pecandu narkotika.

Jaminan perlindungan hukum yang diberikan bagi pecandu narkotika diatur melalui UU No 35 Tahun 2009 Tentang Narkotika dengan memberikan rehabilitasi baik medis maupun rehabilitasi sosial sebagaimana tercantum pada Pasal 54 pada undang-undang narkotika itu. Yaitu bahwa "pecandu narkotika dan pecandu penyalahguna narkotika wajib menjalani rehabilitasi medis dan rehabilitasi sosial"

Kebijakan pemerintah atas perlindungan dan pembinaan terhadap pecandu narkotika didukung oleh terbitnya Surat Edaran Mahkamah Agung Nomor 4 Tahun 2010 agar menjadi pegangan para penegak hukum dalam sistem peradilan pidana, khususnya pertimbangan pada hakim. Pembinaan terhadap pecandu narkoba didukung oleh terbitnya Peraturan Pemerintah Nomor 25 Tahun 2011 Tentang Pelaksanaan Wajib Lapor Pecandu Narkotika. Tujuannya, agar para pecandu narkotika tadi tidak takut untuk melaporkan dirinya ke Institusi Penerima Wajib Lapor (IPWL) yang telah ditunjuk pemerintah, karena dengan payung hukum Pasal 54 dan 103 ayat (1) para pecandu narkotika tidak akan dijebloskan ke dalam penjara jika terbukti hanya mengkonsumsi narkotika dan akan mendapatkan 
layanan rehabilitasi.

Namun, jika mengacu kepada kebijakan pemerintah tadi dan dibandingkan dengan jumlah pemakai narkoba di negeri ini, yaitu mencapai 5,1 juta jiwa orang, maka akan terlihat kerancuan dan inkonsistensi dalam pelaksanaannya. Indikasi itu terlihat dari penaganan terhadap pecandu narkoba di lapangan, diantaranya: ${ }^{11}$

a. Pertama, lembaga pemasyarakata (Lapas) di Indonesia banyak dihuni oleh kasus pelaku narkoba. Mememang, kondisi banyaknya penghuni Lapas karena narkoba perlu di klasifikasikan antara pecandu, kurir, pengedar atau bandar narkoba. Tapi, jika melihat regulasi terkait narkoba itu, sebagaimana menurut UU No 35 Tahun 2009 Tentang Narkotika, pecandu narkoba harusnya mendapatkan rehabilitasi bukan di tahan berlama-lama diLapas.

b. Kedua, indikasi lain yang terlihat atas inkonsistensi pemerintas dalam pelaksanaan UU No 35 Tahun 2009 Tentang Narkotika adalah diperkirakan tidak meratanya atau sebandingnya jumlah IPWL di berbagai daerah dengan jumlah pecandu narkotika. Padahal pecandu narkotika hampir merata diseluruh

\footnotetext{
11 Mas Candra Dewi, A.A.I, 2012. Perlindungan Hukum Terhadap Korban Penyalahguna Narkotika Dengan Berlakunya Undang Undang No 35 Tahun 2009 Tentang Narkotika, Jurnal Program Studi Magister Hukum Program Magister. Bali: Program Pascasarjana UniversitasUdayana.
}

penjuru wilayah.

c. Ketiga, pelaksanaan dekriminalisasi berupa pecandu narkoba mendapatkan rehabilitasi baik medis maupun rehabilitasi sosial, masih belum seluruhnya dipahami masyarakat, khususnya masyarakat yang belum sadar atau melek hukum. Sehingga mendorong rasa takut dan kekawatiran bagi yang malapor. Karena, dalam anggapan masyarakat berurusan hukum sangat menyita waktu dan rumit dan perlu keahlian tersendiri.

d. Keempat, pecandu narkoba atau terlibat narkoba masih dipandang aib atau cela oleh sebagian besar masyarat.

e. Kelima, akses masyarakat terhadap pusat-pusat atau kantor hukum belum merata. Artinya, akses kepada kantor polisi atau instansi IPWL tadi tidak semudah sebagaimana akses di perkotaan atau kota-kota besar, yaitu relatif sangat mudah terjangkau, transfortasi yang mudah terjangkau dan imprastruktur yang relatif lebih baik dibanding daerah-daerah lain di wilayah Negara Kesatuan Republik Indonesia.

Dengan adanya lima hal tadi, maka kebijakan pemerintah dalam menanggulangi pecandu narkotika tidak sepenuhnya terlaksana sebagaimana amanah UU No 35 Tahun 2009 Tentang Narkotika yaitu memberikan pembinaan, perawatan terhadap pecandu narkotika. Artinya, pemerintah masih belum konsisten alias inkonsistensi 
dalam melaksanakan UU No 35 Tahun 2009 TentangNarkotika.

\section{KESIMPULAN}

1. Pemberantasan narkotika tentunya tidak dapat ditekan jika aparat penegak hukum hanya fokus pada level para pengguna. Seharusnya penguna maupun pecandu ditempatkan sebagai korban ataupun pasien yang harus direhabilitasi, dan yang menjadi target operasi kepolisian adalah para pengedar/bandar. Dalam menangkap pengguna maka tentunya dapat membantu untuk menangkap pengedarnya yang kemudian pengguna dengan kategori tertentu dapat dijatuhi vonis rehabilitasi seperti yang diamanahkan dalam Surat Edaran Mahkamah Agung (SEMA) Nomor 7 Tahun 2009 tentang Menempatkan Pemakai Narkoba ke dalam Panti Terapi dan Rehabilitasi. Ruang lingkup hukum pidana mencakup tiga ketentuan yaitu tindak pidana, pertanggungjawaban, dan pemidanaan. Ketentuan pidana yang terdapat dalam UU No. 35 Tahun 2009 tentang Narkotika dirumuskan dalam Bab XV Ketentuan Pidana Pasal 111 sampai dengan Pasal 148. UndangUndang No. 35 Tahun 2009 tentang Narkotika
2. Kebijakan pemerintah atas perlindungan dan pembinaan terhadap pecandu narkotika didukung oleh terbitnya Surat Edaran Mahkamah Agung Nomor 4 Tahun 2010 agar menjadi pegangan para penegak hukum dalam sistem peradilan pidana, khususnya pertimbangan pada hakim. Pembinaan terhadap pecandu narkoba didukung oleh terbitnya Peraturan Pemerintah Nomor 25 Tahun 2011 Tentang Pelaksanaan Wajib Lapor Pecandu Narkotika. Tujuannya, agar para pecandu narkotika tadi tidak takut untuk melaporkan dirinya ke Institusi Penerima Wajib Lapor (IPWL) yang telah ditunjuk pemerintah, karena dengan payung hukum Pasal 54 dan 103 ayat (1) para pecandu narkotika tidak akan dijebloskan ke dalam penjara jika terbukti hanya mengkonsumsi narkotika dan akan mendapatkan layanan rehabilitasi.

\section{DAFTAR PUSTAKA}

Bambang Waluyo, 2013, Viktimologi Perlindungan Hukum Terhadap Korban Kejahatan, Jakarta: Sinar Grafika

Dikdik M. Arief dan Elisatris Gultom, 2013, Urgensi Perlindungan Korban Kejahatan, Jakarta: PT. Raja Grafindo Persada 
Hari Sasangka, 2011, Narkotika dan Psikotropika Dalam Hukum Pidana, Bandung: Mandar Maju,

I Made Pasek Diantha, 2016, Metodologi Penelitian Hukum Normatif dalam Justifikasi Teori Hukum (Jakarta : Prenada Media Grup)

Kaka Alvian Nasution, 2014, Himpunan Lengkap Undang-Undang Narkotika dan Psikotropika, Jogyakarta: Saufa,

Mas Candra Dewi, A.A.I, 2012. Perlindungan Hukum Terhadap Korban Penyalahguna Narkotika Dengan Berlakunya Undang Undang No 35 Tahun 2009 Tentang Narkotika, Jurnal Program Studi Magister Hukum Program Magister. Bali: Program Pascasarjana Universitas Udayana.

Mustafa, Muhammad, Krimonologi, 2007: Kajian Sosiologi terhadap Kriminalitas, Perilaku menyimpang, dan Pelanggar Hukum, FISIP UI Press

Soedjono Dirdjosisworo,2013, Pathologi Sosial, Bandung: Alumni

Siswanto Sunarso, 2012, Politik Hukum Dalam Undang-Undang Narkotika, Jakarta: Rineka Cipta,

JURNAL RECHTENS, Vol. 9, No. 1, Juni 2020
Yusuf Apandi,2012, Katakan Tidak Pada Narkoba, Bandung: Simbiosa Rekatama Mebia

\section{PERUNDANG-UNDANGAN :}

Undang-Undang Nomor 35 Tahun 2009 tentang Narkotika ;

Surat Edaran Mahkamah Agung (SEMA) Nomor 7 Tahun 2009 tentang Menempatkan Pemakai Narkoba ke dalam Panti Terapi dan Rehabilitasi;

\section{INTERNET :}

Bhakti Eko Nugroho, htpp://catatan-orang biasa.blogspot.com/2008/12/benarkah penggu-naan-drugs-adalah.html

\section{BIODATA SINGKAT PENULIS}

Rahmad Teguh adalah Ketua Bidang Perpajakan Persatuan Advokat Indonesia (Peradin). Menyelesaikan pendidikan Sarjana Hukum pada Fakultas Hukum Universitas Narotama,Surabaya pada tahun 2016. Sejak tahun 2019 menempuh program S-2 Magister Hukum di Universitas Narotama Surabaya. 